\title{
Performative Social Science
}

\section{Kip Jones}

Bournemouth University

kipworld@gmail.com

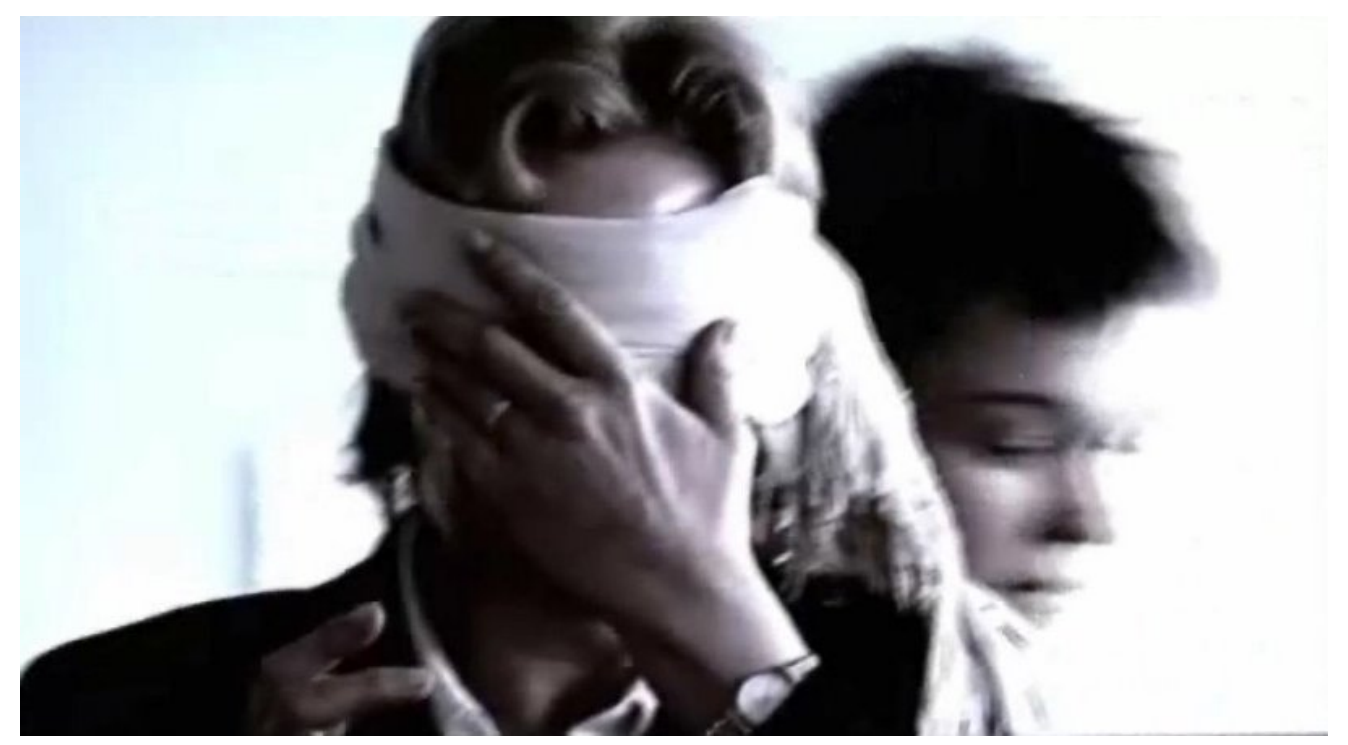

Figure 1. Participants in the AHRC funded workshops, "Social Science in Search of its Muse" held at Bournemouth University 2006-2007.

\section{Abstract}

Performative Social Science is positioned within the current era of crosspollination from discipline to discipline. Practitioners from the Arts and Humanities look to the Social Sciences for fresh frameworks, whist Social Science practitioners explore the Arts for potential new tools for enquiry and dissemination. Performative Social Science is defined and the similarities and differences between PSS and Arts-based Research (ABR) are delineated. The history of PSS is then outlined and its development, particularly at the Centre for Qualitative Research at Bournemouth University in the United Kingdom, is reviewed. Relational Aesthetics is then described in depth as the theoretical basis and grounding of Performative Social Science. Relational Aesthetics (Bourriaud, 2002) offers a theoretical ground for the complexities of connections across seemingly disparate disciplines such as the Arts and Social Sciences and for further exploration of the synergies between both disciplines as well as communities beyond the academy. An example of a large, three-year nationally funded project, culminating with the production of an award-winning short biopic, RUFUS STONE, is outlined as a prime example of a multi-method approach to social science research which includes tools from the arts in its progress and outputs. The entry concludes with goals and aspirations for Performative Social Science in the future.

Keywords: communication, research methods, creativity, narrative, audience, film studies, performative social science, qualitative research, relational communication

\section{Background and Definition}

It is a historical fact that the major upheavals and transformations in Western Art and Science occurred during periods of cross-pollination from discipline to discipline (The Enlightenment or 
Age of Reason, Truth and Beauty in the 18th Century, or Paris at the beginning of the 20th Century and the cross-fertilization between art, music, literature, dance and design, and so forth during these hyper-eras). Forward-looking Arts and Humanities academics are currently directly involved in such cross-disciplinary communication with contemporary practitioners from other disciplines, including the Social Sciences. Some have reached an impasse when re-exploring historical concepts such as the death of the author (Barthes, 1967) in literary criticism and the utility of silence (Sontag, 1967) in fiction. These conundrums, when complicated by contemporary questions in art criticism such as the direct involvement of audience in producing relationships with the world through signs, forms, actions and objects (Bourriaud, 2002) contribute to this contemporary unease. All of these questions challenge the traditional means of production and diffusion in the Arts and Humanities and their respective scholarships.

From a different viewpoint, questions of wider dissemination and methodology itself have begun to convince social scientists to look beyond their own philosophical groundings to aesthetics for solutions. They have found that text is often only linear and, therefore, temporal; in science the meaning must be precise or risk disbelief. Narrated stories turned into written text (the vast majority of the outputs of the Social Science interview culture) now require a fresh approach. The constructed memories that are the building blocks of narrated accounts, like dreams, are simultaneous layers of past and present — the visual and the spatial—and these added dimensions, beyond the purely temporal, now demand attention.

At the same time, practitioners in the Arts and Humanities are looking for a fresh framework within which to base their scholarship and more recently have turned to Social Science for possible suggestions for alternative methodologies and philosophies. There is a desire amongst Arts and Humanities practitioners (photographers and filmmakers, choreographers, poets, composers, creators of new media, etc.) to connect somehow in a relational way to a science of social beings inhabiting space, place and time (communities?), and to investigate scholarly foundations for these explorations. Many scholars in the Arts and Humanities as well as the Social Sciences are now, in fact, exploring what is conceived of as "the Performative".

What is Performative Social Science (PSS) then, Art or Science? It isn't one or the other. It is a fusion of both, creating a new model where tools from the Arts and Humanities are explored for their utility in enriching the ways in which Social Science subjects might be researched and/or disseminated or communicated to various communities. Ideally, audiences should be almost unaware of the seams where practitioners have cobbled together in-depth, substantial scholarship with artistic endeavour. PSS is defined as the use of tools from the Arts or Humanities in investigating and/or disseminating Social Science research.

Performative Social Science and what is sometimes called "Arts-based Research" (ABR) have much in common. PSS is still its own unique paradigm in the Social Sciences, but both concepts (ABR and PSS) occupy the same broad church: the use of the arts in discovery and communication of scholarship. Patricia Leavy defines Arts-based Research "as any social research or human inquiry that adapts the tenets of the creative arts as a part of the methodology. So, the arts may be used during data collection, analysis, interpretation and/or dissemination" (Jones \& Leavy, 2014). PSS, in referencing its similar definition by referring directly and discreetly to both research and dissemination, raises the consideration of audience in all of its undertakings. In addition, the fact that PSS is theoretically grounded in Relational Aesthetics insures that its efforts are not simply "art for arts sake", but involve creativity in social research and its dissemination and involvement with a wide community. Creativity is defined as working within certain boundaries while, at the same time, somehow changing them.

Performative Social Science is currently gaining attention, even popularity, amongst academics who are particularly frustrated with PowerPoint as the only "show and tell" game in town. Over 
time, academic PowerPoint lectures and presentations have devolved into mostly "tell" - slides of text simultaneously recited to captured audiences. Secondly, academic publishing has its limitations in reaching the wider community. The actual readership of academic journal articles is quite low and, by their nature, have a limited readership. New means of including a wider public are needed. Performative Social Science embraces the use of tools from the Arts (e.g., photography, dance, drama, filmmaking, poetry, fiction, etc.) by expanding - even replacingshopworn methods of research and diffusion of academic efforts. A third potential of these new Arts-based methods of exploration and dissemination is inclusion in these processes of the very communities that we research and/or try to reach with our investigations. When all three elements (Research/Dissemination/Community) are based in an Arts-based approach and are working in tandem, Performative Social Science is at its best.

"Performative Social Science" was a term first coined by Norman Denzin in 2001 (Denzin 2001); around that time, researchers had begun to reconstruct the interview in what Denzin described as "not as a method of gathering information, but as a vehicle for producing performance texts and performance ethnographies about self and society"' (2001, p. 24) where "text and audience come together and inform one another" (2001, p. 26) in a relational way. Law and Urry (2004) proposed that research methods in the Social Sciences do not simply describe the world as it is, but also enact it (2004, p. 391). They are performative; they have effects; they make differences; they enact realities; and they can help to bring into being what they also discover (2004, pp. 392-93). Indeed, "to the extent Social Science conceals its performativity from itself it is pretending to innocence that it cannot have" (2004, p. 404).

The use of tools from the Arts and Humanities, in both investigation of concerns and dissemination of data, began to gain critical mass amongst social scientists. Photography, music, dance, poetry, video installations, dramatic monologues and theatrical performances were all added to the researcher's toolbox under the umbrella paradigm of "Performative Social Science". In turn, those in the Arts and Humanities began turning to PSS in order to establish a methodological base and explore ways of engaging with and reaching diverse communities with their own creative outputs. Because of its natural requirement for community, Performative Social Science provides the overarching intellectual prowess, strategies and methodological and theoretical depth to engage and unite scholars across disciplines and, in turn, connect researchers' endeavors with communities and stakeholders.

What "performative" refers and relates to in these contributions and elsewhere is the communicative powers of research and the natural involvement of an "audience," whether that be connecting with groups of citizens, peers or students, a physical audience or a cyber audience, even a solitary reader of a journal or a book. This is good news, not only for participants in research studies, who can often be involved in producing subsequent performative outputs, but also for the larger community to whom these findings should be not only directed, but also connected.

How does such an effort contribute to traditional academic values? "This will be uncomfortable. Novelty is always uncomfortable. We shall need to alter academic habits and develop sensibilities appropriate to a methodological decentring" (Law \& Urry, 2004, p. 404).

\section{Relational Aesthetics - a theoretical grounding for Performative Social Science}

Where do we find an aesthetic in which to base a performative Social Science? "The criteria for evaluating qualitative work ... are moral and ethical. Blending aesthetics (theories of beauty), ethics (theories of ought and right) and epistemologies (theories of knowing), these criteria are fitted to the pragmatic, ethical and political contingencies of concrete situations" (Denzin \& Lincoln, 2002, p. 229). 
The 20th Century was not kind to 18th Century notions of the aesthetic. With Social Constructionism's principles in mind, 21st Century ideas of what "truth" and "beauty" mean need to be re-examined from a local, quotidian vantage point, with concepts such as "aesthetic judgment" located within community. The principles of Nicolas Bourriaud's Relational Aesthetics (Bourriaud, 2002) offer one theoretical grounding to the search at hand, basing theories of Art in terms of co-operation, relationship, community and a broad definition of public spaces. Bourriaud's Relational Aesthetics are suggested as a starting point because Bourriaud offers a post-modern, contemporary framework that allows social scientists to think about aesthetics and means of dissemination in refreshing ways. Relational Aesthetics also forms a structure on which we can begin to think about a "performative" Social Science-a science that includes more emphasis on collaborations with our research participant co-authors, co-producers or co-performers themselves. It also provides a platform on which to base the production values of our dissemination efforts and gauge the effects that our fabrications have on our audiences as well, allowing for their own participation in a dialogical, creative social exchange.

As a young art critic in the 1990s, Bourriaud used the term "Relational Art" to describe a set of artistic practices that take as their theoretical departure human interactions and their social contexts. Relational Art bridges or blurs the differences between life and Art and involves the public as co-creators of artworks; i.e., Art becomes socially constructed (Ekholm, 2004, p. 3). Central to its principles are inter-subjectivity, being-together, the encounter and the collective elaboration of meaning, based in models of sociability, meetings, events, collaborations, games, festivals and places of conviviality. By using the word "conviviality", the emphasis is placed on commonality, equal status and relationship (Hewitt and Jordon, 2004, p. 1). Relational Aesthetics or "socializing Art" often comprises elements of interactivity, but its most noticeable characteristic is its socializing effect. Through such efforts, it aims to bring people together and to increase understanding (Johansson, 2000, p. 2). In fact, Bourriaud believes that Art is made of the same material as social exchanges. If social exchanges are the same as Art, how can we portray them?

Relational artistic activity, "strives to achieve modest connections, open up (one or two) obstructed passages, and connect levels of reality kept apart from on another" (Bourriaud, 2002, p. 8). Key to Relational Aesthetics is the guiding principle that Relational Art (an Art taking as its theoretical horizon the realm of human interactions and its social context, rather than the assertion of an independent and private symbolic space) points to a radical upheaval of the aesthetic, cultural and political goals introduced by modern art. Relational Aesthetics looks towards the possibility of reduction of the inter-personal distance by the development of sensibility for the intuitive and associative aspect of communication contributing to and expanding the reflective and dialogic approaches of contemporary biographic Social Science through concepts of improvisation and spontaneity within a renewed concept of participantcommunity.

Art, in Relational Aesthetics, is seen as a state of encounter and the essence of humankind, purely trans-individual and made up of bonds that link individuals together in social forms which are invariably historical (Bourriaud, 2002, p. 18).

- The small spaces of daily gestures determine the superstructure of "big" exchanges and are defined by it (Bourriaud, ibidem, p. 17).

- Art in post-modern times is concerned with occupying time, rather than occupying space (Bourriaud, ibidem, p. 32).

- Social exchanges consist of interactivity with the viewer, and as a tool serving to link individuals and human groups through a preference for contact and tactility (Bourriaud, ibidem, p.43). 
Bourriaud emphasizes that we have the right to query every aesthetic production whether an Art work allows us to take part in the dialogue, whether we can conceive our existence and in which way, within the semantic space which that work defines. Strategically, for social scientists, relational aesthetics are present when inter-human exchanges become aesthetic objects in and of themselves (Yorke, 2004, p. 2). Co-operation, co-production and collaboration become things of aesthetic beauty. There is not necessarily an "object" in the traditional sense of Art, but rather a time, a space and a gathering, creating a transitory, participant community.

Bourriaud concludes: "It seems more pressing to invent possible relations with our neighbours in the present than to bet on happier tomorrows" (Bourriaud, 2002, p. 45).

- Relational aesthetics see the everyday, or the quotidian, as a much more fertile terrain (Bourriaud, ibidem, p. 47).

- "We find in pride of place a project to rehabilitate the idea of Beauty" (Bourriaud, ibidem, p. 62).

- Our intentions need to consist of conveying the human sciences and the Social Sciences from "scientistic paradigms to ethical - aesthetic paradigms" (Guattari cited in Bourriaud, ibidem, p. 96).

Because Relational Art takes as its starting point human relations and their social context, as social scientists engaged in the (re)presentation of the storied nature of everyday events, we share a starting point with our artistic contemporaries. Relational aesthetics judges artworks in terms of the inter-human relations which they show, produce, or give rise to (Dezeuze, 2005, p. 18); this principle, therefore, locates our common ground.

Relational Aesthetics (Bourriaud, 2002) offers a theoretical ground for the complexities of connections across seemingly disparate disciplines such as the Arts and Social Sciences and for further exploration of the synergies between both disciplines as well as communities beyond the academy. Bourriaud's Relational Aesthetics is suggested as a starting point because it offers a post-modern, contemporary framework that allows academics to think about aesthetics and the use of platforms from the Arts across disciplines in refreshing ways. Relational Art is located in human interactions and their social contexts. Central to it are inter-subjectivity, being-together, the encounter and the collective elaboration of meaning, based in models of sociability, meetings, events, collaborations, games, festivals and places of conviviality. By using the word "conviviality," the emphasis is placed on commonality, equal status and relationship (Hewitt \& Jordan, 2004. p. 1). Relational Aesthetics or "socializing Art" often comprises elements of interactivity, but its most noticeable characteristic is its socializing effect.

Through such efforts, it aims to bring people together and to increase understanding (Johannsen, 2000, p. 2). Performative Social Science challenges the traditional binary between research and (re)presentation, that is, between acts of observing or "gathering data" and subsequent reports on this process (Gergen \& Gergen, 2003). Text is often only linear and, therefore, temporal; in text the meaning must be precise or risk disbelief. Conversely, "working visually involves a significant shift away from the often oddly lifeless and mechanical accounts of everyday life in textual representation, towards ... engagements that are contextual, kinesthetic and sensual: that live" (Halford \& Knowles, 2005, p. 1), the realisation, perhaps, of what Denzin forecast as "the cinematic interview society" (Denzin, 2001, p. 23).

\section{Development of Performative Social Science}

Performative Social Science began to be developed in earnest at Bournemouth University's Centre for Qualitative Research in 2005. Through initial efforts, a series of five workshops, "Social Science in Search of its Muse: Exploratory Workshops in Arts-related Production and Dissemination of Social Science Data," were held at Bournemouth University from November, 2006 through June, 2007, supported by the Arts \& Humanities Research Council (AHRC), and 
funded under its Nature of Creativity Scheme. These efforts were put forward in order to indicate means with which social scientists could benefit by identifying areas of possible connections with each other as well as with practitioners from the Arts. Participants were able to return from these encounters across disciplines to more traditional fields of endeavor with renewed possibilities for creative and innovative exploration of knowledge production and diffusion. Since this seminal effort in PSS, the impact of these explorations has been measurable, including several completed PhDs utilizing principles of PSS, many journal articles, films and conference presentations nationally and internationally and further funding by Research Councils UK of research based in Performative Social Science methods.

At the end of the initial four workshops, a short film was made (See Figure 1.) which acted as a record of the events as well as an audio/visual evaluation tool. The film, "Social Science finding its muse", (See "Further Reading") was premiered at "Qualitative research and Arts practice: The potential for research capacity building," ESRC National Centre for Research Methods, University of Wales - Cardiff, September, 2007. It was an invited presentation at Bristol University's Postgraduate School of Education as an exemplar of "Facilitated Learning." It was also entered into the Learning on Screen Awards 2008 competition. The film has been available on the Internet since September 2007 and has had many thousands of viewings globally since that time.

A Special Issue on Performative Social Science (See Further Reading) for the online, qualitative journal, Forum: Qualitative Social Research (Jones et al., May, 2008), provided a wide range of examples and manifestations of PSS, with contributions from various disciplines/subject areas, and realized through a wide variety of approaches to research practice. The Special Issue contained over 100 photographs and almost 50 illustrations, as well as 36 videos and two audiorecordings. Forty-two articles were produced by contributors from 13 countries (Australia, Austria, Canada, Chile, Columbia, Denmark, Finland, Germany, New Zealand, Spain, the Netherlands, the United Kingdom, and the United States of America) and written in three languages.

Over $40 \%$ of the abstracts submitted for Bournemouth's Centre for Qualitative Research 2010 biennial conference involved Performative Social Science. The conference became the first international gathering of scholars committed to the use of PSS in their work and was highlighted in a report by BBC News (See Further Resources). Work in Performative Social Science continues at Bournemouth, with Seminars, Masterclasses ("Turning Research into Film", etc.), the formation of a cross-faculties ARTS in Research collaborative, and several PhD theses successfully submitted using a PSS approach.

\section{Recent progress: a multi-method project that led to making a professionally produced film}

A recent three-year project that took place at Bournemouth University as part of the New Dynamics of Ageing Programme (a unique collaboration between five UK Research CouncilsESRC, EPSRC, BBSRC, MRC and AHRC) on ageing in 21st Century Britain provides an example of the use of PSS and connectivity to community. The project was entitled, "Gay and Pleasant Land? - a study about positioning, ageing and gay life in rural South West England and Wales". Through an exploration of the recollections, perceptions and storied biographies of older lesbians and gay men and their rural experiences, the project focused on connectivity and the intersections between place, space, age and identity. Connectivity and identity were central concepts within the project, developing an understanding of how sense of belonging may be negotiated within a rural context. Connectivity can be understood as the ways in which individuals identify and connect themselves with others and the ways in which this may be filtered by aspects of their age and sexuality. Identity and the ways in which older lesbians and gay men choose to disclose their sexuality as part of their identity exerts an influence on the ways in which individuals make connections within the wider community. 
The biographies of older lesbians and gay men and their rural experiences formed the bulk of the data studied and the basis for the story and characterisation of a short professionally made film RUFUS STONE, a unique collaboration between Josh Appignanesi, Director (The Infidel; Ex Memoria) and Kip Jones, Executive Producer and Author. (See Further Reading for link to film.) The project included such arts-based methods as Visual Ethnography, theatrical interpretation of data, and Auto-ethnography within a multi-method approach. This project would have been impossible without the active participation of community partners as advisors and participants over the period of the study, many who continue to actively engage enthusiastically in the dissemination of the film. The project aimed to empower older lesbians and gay men in rural areas through a collaborative multi-method participatory action research design that continues to embrace the principles of PSS in its dissemination plan. The projected impact of the film is to begin to change minds, change attitudes and help to build communities where tolerance and understanding are keys to connectivity and to increasing the value of the social capital of all citizenry in rural settings. By using film and the facility of "entertainment" to suspend disbelief, the potential to change hearts and minds became possible.

\section{Future goals and aspirations}

The goals of a Performative Social Science are:

1. To dramatically demonstrate through meaningful community impact, the value and worth of in-depth, well-financed Social Science research interpreted and/or disseminated through use of tools from the Arts and Humanities;

2. To further substantiate the theory of Performative Social Science in which community is central to (re)discovering meaning and utility through a Relational Art (Bourriaud, 2002), located in human interactions and their social contexts. Central to Relational Art are inter-subjectivity, being-together, the encounter and the social construction of meaning; and

3. Through relational artistic activity, to strive "to achieve modest connections, open up (one or two) obstructed passages, and connect levels of reality kept apart from one another" (Bourriaud, 2002, p. 8).

Objectives include the following:

1. To establish a 'space and place' for novel interactions-both with each other as well as with external communities, to include fresh interfaces with data itself-providing a new environment for invention, inspiration and collaboration.

2. To build a critical mass of Social Science researchers and postgraduates with a renewed confidence in exploration and use of tools from the Arts and Humanities in production and dissemination of Social Science data.

3. To forge new collaborations and networks with individuals in the Arts and Humanities and,

- To engage in on-going dialogue across disciplines through new networks, leading to,

- Collaborative production and diffusion of Social Science outputs and community dialogue.

A founding principle of Performative Social Science is a desire to reach wider audiences with research efforts. We look beyond academic journals or narrow academic subject groups for new audiences where the benefits of our scholarly activities will encourage meaningful communication and dialogue within communities of everyday citizens. 


\section{IECRM0163 IECRM0184 IECRM0262}

\section{Further Reading}

Gergen M., Gergen, K. (2012) Playing with Purpose Walnut Creek, CA: Left Coast Press.

Jones, K. et al. (2008) "Performative Social Science” Special Issue Forum: Qualitative Social Research, 9, 2. Retrieved from http://www.qualitative-research.net/index.php/fqs/issue/view/10

Jones, K. (2006) “A Biographic Researcher in Pursuit of an Aesthetic: The use of arts-based (re)presentations in "performative" dissemination of life stories" Qualitative Sociology Review, II, 1. Retrieved from http://www.qualitativesociologyreview.org/ENG/Volume3/Article5.php

Jones, K. (2012) "Connecting Research with Communities through Performative Social Science” The Qualitative Report, 17(Rev. 18), 1-8. Retrieved from http://www.nova.edu/ssss/QR/QR17/jones.pdf

Jones, K. (2013) "Infusing Biography with the Personal: Writing RUFUS STONE" Creative Approaches to Research 6, 2: 6-23. Retrieved from: http://aqr.org.au/wpcontent/uploads/2012/07/CAR6_2_FULL.pdf

Leavy, P. (2015) Method Meets Art: Arts-Based Research Practice ( $2^{\text {nd }}$ Ed.) New York, NY: Guilford Press.

\section{Videos}

BBC News (2010) "Alternative ways of getting your message across". (Broadcast video) David Sillito Reports 23 September 2010. Retrieved from http://www.bbc.co.uk/news/uk-11396474.

Jones, K. (Exec Prod) (2012) RUFUS STONE (short film) Retrieved from https://vimeo.com/109360805

Jones, K. (Exec Prod) (2007) "Social Science discovering its muse" (video) Retrieved from https://vimeo.com/4327950

Jones, K. (Writer/Prod) (2010) "I Can Remember the Night" (video) Retrieved from https://vimeo.com/4352507

\section{Community resources}

Performative Social Science on Facebook:

https://www.facebook.com/groups/120763824633892/

To subscribe to the PerformSocSci email newsgroup go to:

http://tinyurl.com/ydkjuqj

\section{References}

Barthes, R. (1967). Death of the author. Aspen Magazine, Retrieved from: https://www.academia.edu/3493011/1967 The Birth of The Death of the Author Authorfinal version as archived at University of Minnesota Digital Conservancy

Bourriaud, N. (2002; English version). Relational aesthetics. Dijon, France: Les Presses du Reel.

Denzin, N. K. (2001). The reflexive interview and a performative social science. 
Qualitative Research, 1(1): 23-46.

Denzin, N, K., Lincoln, Y.S. (2002) (Eds) The Qualitative Inquiry Reader. Thousand Oaks, CA: Sage.

Dezeuze, Anna (2005) “Transfiguration of the Commonplace.” Variant 2(22).

Retrieved from http://www.variant.org.uk/22texts/Dezeuze.html

Gergen, M. M., \& Gergen, K. J. (2011, Draft). Playing with purpose: Adventures in performative social science. Walnut Creek CA: Left Coast Press.

Ekholm, Rickard (2004) "Rene-NU-E-Bridging the gap." 16 Beavergroup web page. Retrieved from: http://16beavergroup.org/articles/2004/04/15/rene-nu-e-bridging-the-gap/

Hallford, S., \& Knowles, C. (2005). More than words: Some reflections on working visually. Sociological Research Online, 10(1). Retrieved from

http://ideas.repec.org/a/sro/srosro/2005-25-1.html

Hewitt, A., Jordan, M. (2004) “Talking up the social.” Web page: Press Corps of the 2004, Liverpool Biennial. Retrieved from http://www.everydayarchive.org/presscorps/writing/hewitt-jordan.pdf

Johannson, T. D. (2000). Visualising relations: Superflex' relational art in the cyberspace geography. Paper for the Asia Europe Forum 2000, Kyongiu, South Korea, October 23-25, 2000. Retrieved from http://www.itu.dk/people/tdj/paper4.pdf

Jones, K. (Special Issue Editor) with Gergen, M., Guiney Yallop, J. J., Lopez de Vallejo, I., Roberts, B., \& Wright, P. (Co-Eds). (2008). Forum: Qualitative Social Research Special Issue on Performative Social Science (42 articles), 9(2) (May 2008). Retrieved from http://www.qualitative-research.net/index.php/fqs/issue/view/10

Jones, K., Leavy, P. (2014) A Conversation Between Kip Jones and Patricia Leavy: Arts-Based Research, Performative Social Science and Working on the Margins The Qualitative Report, 19(38), 1-7. Retrieved from http://www.nova.edu/ssss/QR/QR19/jones38.pdf

Law, John and John Urry (2004) "Enacting the social." Economy and Society 33(3): 390-410.

Sontag, S. (1967). The aesthetics of silence. Aspen Magazine, pp. 5-6. Retrieved from http://www.ubu.com/aspen/aspen5and6/threeEssays.html\#sontag

Yorke, Zachary (2004) "Unpacing the conceptual underpinnings of Edward Young's 'Asshole'." Artthrob, January 14. Retrieved from http://www.artthrob.co.za/04feb/reviews/bbr2.html

\section{Brief Biography}

Kip Jones BA MSc PhD is Reader in Performative Social Science (PSS) in the Faculties of Media \& Communication and Health \& Social Sciences at Bournemouth University in the United Kingdom. PSS uses tools from the Arts \& Humanities in researching and/or disseminating Social Science research. 
Jones acted as Executive Producer and Author of the award-winning short biopic RUFUS STONE (2012). This effort was the main output of a three-year project funded by Research Councils $U K$ that explored the biographies of older gay and lesbian citizens and their experiences of rural life in Britain. This professionally made film was created by means of a unique collaboration between the film director, Josh Appignanesi (The Infidel), and Jones.

Jones' accomplishments have been reported widely in the media, including: BBC Radio 4, BBC TV news, Times Higher Education, LSE Impact Blog, Sunday New York Times, International Herald-Tribune and The Independent. 